\title{
MAKNA PERNIKAHAN \\ MENURUT SUDUT PANDANG TOKOH ROS MINI \\ DALAM DOKUMENTER POETIC “MINI STORY”
}

\author{
Abdurrahman Kholid Rusadi \\ Agnes Widyasmoro \\ Andi Nur Patrio \\ Jurusan Film \& Televisi, Fakultas Seni Media Rekam, Institut Seni Indonesia Yogyakarta \\ Jl. Parangtritis km. 6.5 Yogyakarta Telp. (0274) 381047
}

\begin{abstract}
ABSTRAK
Film dokumenter poetic " M INI STORY" mengangkat tentang seorang perempuan yang menjalani pernikahan hasil perjodohan dan pernikahan anak usia dini. Perjodohan dan pernikahan anak berkaitan dengan tradisi dan budaya, sehingga sulit untuk mengubahnya. Alasan ekonomi, harapan mencapai keamanan sosial dan finansial setelah menikah menyebabkan banyak orangtua mendorong anaknya menikah di usia muda.

Film dokumenter ini dikemas dengan bentuk poetic. Menurut Bill Nichols bentuk poetic mengorbankan kontinuitas dalam pengeditannya, lebih memfokuskan pada perasaan yang spesifik terjadi pada kejadian dan tempat yang mengikutinya. Bentuk poetic pada film ini dibangun menggunakan semiotika. Metafora merupakan bagian dari ikon dalam teori semiotika Charles S. Pierce.

Penciptaan karya film "MINI STORY" digunakan untuk menyampaikan perasaan Ros Mini dan sutradara sebagai anak kandungnya. Ros Mini tetap menyayangi anaknya meski mengalami keterpaksaan dalam pernikahannya. Dokumenter poetic berangkat dengan tujuan memberikan sudut pandang subjektif dari sutradara terhadap Ros Mini. Emosi yang disampaikan pada penonton adalah emosional sutradara dalam menyikapi kasus yang terjadi dalam film "MINI STORY”.
\end{abstract}

Kata Kunci: Dokumenter, Poetic, Pernikahan, Semiotika,

\section{ABSTRACT}

The poetic documentary "MINI STORY" tells the story of a woman who undergoes marriage as a result of marriage and early childhood marriage. Marriage and child marriage are related to tradition and culture, so it's hard to change that. Economic reasons, the hope of achieving social and financial security after marriage causes many parents to encourage their children to marry at a young age.

This documentary is packed with poetic forms. According to Bill Nichols the poetic form sacrifices continuity in his editing, focusing more on the specific feelings that occur in the events and places that follow him. The poetic form of the film is constructed using semiotics. Metaphors are part of the icon in Charles S. Pierce's semiotic theory.

The creation of the film "MINI STORY" was used to convey the feelings of Ros Mini and the director as her biological child. Ros Mini still loves her children despite the compulsion in her marriage. Poetic documentaries set out with the aim of providing a subjective point of view from the director towards Ros Mini. The emotion conveyed to the audience is the director's emotional response to the case that occurred in the film "MINI STORY".

Keywords : Documentary, Poetic, Marriage, Semiotics, 


\section{Pendahuluan}

Pernikahan biasanya dilakukan oleh orang dewasa dengan tidak memandang pada suku, ras, miskin atau kaya, tinggal di kota ataupun di desa. Kini manusia yang sudah memiliki kemampuan baik fisik maupun mental akan mencari pasangan yang dikehendakinya. Hal itu bertujuan untuk mencapai kebahagiaan dalam sebuah pernikahan.

Perjodohan ternyata masih menjadi tradisi di kalangan tertentu. Walaupun masyarakat memandang bahwa perjodohan sudah kuno seperti jaman Siti Nurbaya, tetapi pada kenyataannya proses pernikahan karena perjodohan masih ditemui di masyarakat.

Perjodohan akan menimbulkan dampak psikologis terhadap seseorang yang mengalaminya. Perkawinan karena perjodohan terindikasi mengalami keterbelakangan mental. Pada dasarnya perjodohan bukanlah hal yang mudah. Biasanya orang tua menjodohkan anaknya kepada seseorang yang menurutnya terbaik bagi anaknya, namun orang tua tidak memikirkan dampak yang akan dialami oleh anaknya akibat ketidaksiapan mental.

Selain perjodohan, perkawinan usia dini juga masih marak di Indonesia. Menurut Child Marriage Report tahun 2020 (Hakiki, Ulfah, \& dkk, 2020) perempuan yang menikah sebelum berusia 18 tahun di tahun 2018 diperkirakan mencapai 1.220.990 orang. Jumlah ini menempatkan Indonesian pada 10 negara absolut perkawinan anak tertinggi dunia. Dalam sepuluh tahun terakhir, hanya ada penurunan kecil untuk perkawinan anak di Indonesia yaitu 3,5 persen. Provinsi dengan prevalensi perkawinan anak tertinggi adalah Sulawesi Barat, Sulawesi Tengah dan Sulawesi Tenggara. Menurut angka absolut kejadian perkawinan usia anak, Jawa Barat, Jawa Timur dan Jawa Tengah adalah 3 provinsi yang paling tinggi.

Suatu studi literasi UNICEF (Fadlyana \& Larasaty, 2016: 137) menemukan bahwa interaksi berbagai faktor menyebabkan anak beresiko menghadapi pernikahan usia dini. Diketahui secara luas bahwa pernikahan anak berkaitan dengan tradisi dan budaya, sehingga sulit untuk mengubahnya. Alasan ekonomi, harapan mencapai keamanan sosial dan finansial setelah menikah menyebabkan banyak orangtua mendorong anaknya menikah di usia muda.

Ros Mini adalah salah satu orang yang mengalami perjodohan dan pernikahan dini. Beliau tinggal di dalam keluarga sederhana di sebuah desa yang masih menjadikan praktik perjodohan sebagai hal yang lumrah. Uniknya ibu Ros Mini ini memiliki profesi sebagai seorang perias pengantin, sebuah profesi yang 
berhubungan erat dengan pernikahan. Kebanyakan orang menjauhi segala sesuatu yang berhubungan dengan pengalaman terburuk mereka, berbeda dengan ibu Ros Mini yang malah berkecimpung di dalamnya. Akibat dari pernikahannya dimasa lalu, banyak hal yang hilang dalam hidup Ros Mini. Dampak nyang paling dirasakan oleh Ros Mini adalah depresi berkepanjangan yang menyebabkan kondisi tubuhnya melemah. Akibat pernikahan yang di paksakan, ibu Ros Mini harus merelakan segala cita-citanya. Beliau memiliki cita-cita mengenyam pendidikan setinggi-tingginya dan menjadi seorang dokter. Meski demikian ibu Ros Mini amat menikmati profesinya sebagai seorang perias pengantin.

Ibu Ros Mini tetap bertahan dalam pernikahannya, sembari terus mencari pemaknaan dari pernikahan yang dia jalani. Setelah sekian lama, beliau akhirnya berhasil menemukan makna pernikahannya. Pernikahannya menjadi bermakna ketika beliau melahirkan anak pertama.

\section{Pembahasan}

Film dokumenter "MINI STORY" merupakan sebuah film yang menceritakan kisah hidup seseorang yang mengalami praktik perjodohan. Menggunakan voice over, jalan cerita film “MINI STORY” layaknya seperti sedang mendengarkan dongeng. Voice over dalam film ini akan dibawakan langsung oleh sutradara. Film "MINI STORY" ini akan terfokus pada pengalaman emosional sang sutradara. Pengalaman emosional ini didapatkan setelah mendengarkan kisah hidup ibu Ros Mini. Pengalaman emosional yang kemudian akan diterjemahkan dalam bentuk audio dan visual.

Struktur penceritaan dalam film "MINI STORY" ini akan menggunakan struktur penceritaan linier. Film ini akan mengikuti perjalanan masa lalu sang narasumber dari sebelum pernikahan sampai dengan keadaan keluarganya sekarang.

Sutradara menjatuhkan pilihannya kepada gaya poetic untuk merealisasikan idenya tersebut. Alasan pemilihan gaya poetic adalah karena gaya ini lebih mampu memberikan penekanan pada suasana hati, nada dan mempengaruhi lebih dari sekedar persuasi sehingga mampu menciptakan empati. Hal itu sesuai dengan keinginan sang sutradara untuk memposisikan penonton sama seperti dirinya dan harapannya, penonton juga bisa ikut merasakan apa yang dirasakan oleh sang sutradara.

Perasaan tersebut akan ditransfer dalam bentuk narasi dan visual menggunakan metafora sebagai elemen pembangun gambar. 
Metafora adalah ikon yang didasarkan atas similaritas di antara objek-objek dari dua tanda simbolis. (Budiman, 2011:88)

Objek estetis natural akan digunakan untuk membangun sebuah ikon metaforis dalam teori Charles S. Peierce. Objek estetis natural adalah benda natural, energi (kegiatan) natural dan bahasa natural.(Junaedi, 2017: 160) Metafora lah yang nantinya akan membangun gaya poetic dalam film “MINI STORY”. Suara dan gambar akan di jadikan meta-tanda (meta sign) yang diantaranya memiliki similaritas dan membentuk sebuah ikon yang berbentuk metafora.

Tokoh utama dalam film "MINI STORY' akan diumpamakan seperti penyu yang semenjak hari pertama menetas akan langsung mengarah ke pantai. Dalam film "MINI STORY”, penyu itu tidak dapat pergi ke laut dan terjebak di pantai. Sang tokoh utama akan mencari cara lain supaya bisa pergi dari tempat itu tapi tidak bisa.

Karakteristik penyu memiliki kesamaan dengan karakteristik perempuan. Penyu akan kembali ke pantai tempat mereka menetas untuk bertelur disana. Karakteristik itu sama seperti seorang perempuan. Ketika dalam kondisi mengandung, mereka akan belajar menjadi seorang ibu kepada ibunya. Itu alasan mengapa penyu di jadikan metafora untuk tokoh Ros Mini.

Gaya poetic dalam film ini terlihat dari pemilihan gambar yang dibangun dan suara yang melatarinya. Format film yang akan dibentuk dari gabungan animasi dan video asli sebagai latarnya. Hai ini bertujuan agar visual yang dihasilkan mampu menyampaikan imajinasi dari sang sutradara.

Bentuk animasi dalam film ini adalah animasi dua dimensi. Animasi dibangun dari garis yang tak konsisten di setiap framenya. Hal itu bertujuan untuk membuat animasi terlihat lebih ekspresif dan seolah memiliki jiwa. Bentuk ekspresif dan jiwa dalam animasi ini adalah bersumber dari pembuat animasi itu sendiri, animator dalam film "MINI STORY' adalah sutradara dan sekaligus anak dari Ros Mini. Pemilihan warna animasi tokoh ibu adalah putih. Putih dalam tokoh ibu dipilih untuk menggambarkan kekosongan jiwa, ketulusan dan gabungan segala warna.

Warna biru untuk tokoh anak lakilaki menggambarkan lautan yang dalam film ini menjadi metafora dari impian besar yang dimiliki oleh tokoh ibu. Anak pertama memiliki sifat yang tenang namun ada masanya dia menjadi pemarah. Sifat yang dimiliki oleh anak pertama sapa seperti sifat lautan. Pada pagi hari laut akan terasa tenang dan pada sore hari laut 
akan menghantamkan ombaknya dengan keras.

Warna jingga kemerahan untuk tokoh anak perempuan pertama adalah mewakili kehangatan dari langit sore. Ketika laut sedang kencang-kencangnya menghantamkan ombak ke pantai, cahaya senja menghangatkan tokoh ibu. Peran itu yang dimiliki oleh anak perempuan pertama. Ketika kakaknya sedang dalam kondisi marah pada ibunya, sang adik perempuan pertama yang menguatkan sang ibu.

Warna hijau dari tokoh anak perempuan kedua mewakili kesejukan dari pepohonan. Ketika langit sedang terik dan laut sedang dalam keadaan tidak tenang, ibu berteduh di bawah rindangnya pepohonan. Peran Anak perempuan kedua dalam kehidupan nyata memang menjadi penguat organik ketika ibunya berada dalam kondisi terpuruk.

Wara hitam dari tokoh ayah menggambarkan sesuatu yang jauh berbeda dari tokoh ibu. Hitam bukan elemen pembentuk putih, hal itu yang membuat mereka saling bersinggungan dan tak bisa saling berhubungan. Ketika laut, langit sore dan pepohonan tersapu gelap, ibu tidak bisa berbuat apa-apa.

Menjadi perias pengantin adalah pekerjaan Ros Mini yang memberikan kebahagiaan bagi dirinya. Dalam pekerjaannya sebagai perias pengantin, beliau menemui banyak cerita cinta yang unik. Ibu Ros Mini merasakan kebahagiaan ketika bisa berkontribusi dalam kebahagiaan pernikahan orangorang. Tidak hanya kebahagiaan, rasa sedih juga kerap Ros Mini alami. kesedihan itu beliau rasakan ketika mengetahui orang yang beliau rias wajahnya mengalami hal serupa dengannya.

Film ini akan dibagi menjadi enam segmen. Segmen pertama akan menceritakan bagaimana seorang Ros Mini yang harus merelakan cita-cita besar dalam hidupnya akibat perjodohan yang dialaminya. Kemudian segmen kedua adalah menceritakan kejadian yang dramatis ketika beliau melarikan diri dari rumah. Segmen ke tiga akan menceritakan bagaimana perasaan Ibu Ros Mini ketika pernikahannya sedang berlangsung. Segmen ke empat akan menceritakan ketika beliau melahirkan anak pertama. segmen ke lima adalah konflik yang terjadi antara Ibu Ros Mini dan suaminya setelah anak pertamanya keluar dari rumah. Segmen ke enam memperlihatkan pertemuan Ibu Ros Mini dengan anak pertamanya yang menganggap ibunya telah mengkhianati keluarga

Segmen pertama akan diawali dengan proses merias pengantin yang dilakukan oleh Ros Mini. Dalam segmen ini akan diperlihatkan anak kecil yang 
didandani menjadi seperti pengantin adat sunda. Setelah proses merias selesai, tibatiba wajah anak kecil itu berubah menjadi wajah Ros Mini. Ros Mini perlahan berubah menjadi animasi. Segmen ini menceritakan rekontruksi kejadian pernikahan dini yang Ros Mini alami.

akan banyak menggunakan lokasi pantai sebagai latar tempatnya. Hal itu bertujuan untuk menyesuaikan isi segmen dengan semiotika yang dibuat oleh sutradara. Ketika sutradara menceritakan cita-cita Ros Mini yang besar, gambar akan memperlihatkan hamparan laut yang luas. Ketika beliau menceritakan semangat belajar Ros Mini dalam menuntut ilmu, gambar akan memperlihatkan ketika anak-anaknya sedang bermain di tepi pantai. Semangat yang menggebu-gebu dimasa mudanya akan di gambarkan dengan deburan ombak yang besar. Ketika pernikahan memupuskan seluruh impiannya, shot akan memperlihatkan Ros Mini menatap ke arah pantai dan kemudian suaminya mendekati dan duduk di sampingnya. Shot selanjutnya adalah garis pantai yang menjadi penggambaran pernikahan sebagai garis yang memisahkan antara beliau dan impiannya. Ibu Ros Mini berjalan menuju garis pantai itu dan memandangi impian besarnya yang tak mampu dia capai.
Segmen kedua akan menceritakan salah satu kisah dramatis, bagaimana ibu Ros Mini memutuskan pergi dari rumah dan bersembunyi di rumah temannya. Setelah pihak keluarga mengetahui bahwa dia pergi dari rumah, kakaknya menyusul ke tempat persembunyiannya. Sang kakak menyarankan untuk pergi ke tempat saudaranya yang ada di Jambi dan berangkatlah mereka ke Jambi. Sepulangnya dari Jambi ternyata ibu Ros Mini mengetahui bahwa rencana sebenarnya sang kakak adalah untuk menghentikannya melanjutkan sekolah.

Segmen ke tiga adalah ketika beliau menceritakan bagaimana pernikahannya saat itu, gambar yang akan ditampilkan adalah ketika beliau melakukan pekerjaannya sebagai perias pengantin. Sang sutradara menceritakan perasaan Ibu Ros Mini pada saat kejadian itu. Gambar yang akan ditampilkan adah ketika beliau merias pengantin. Kemudian di tambah dengan gambar-gambar suasana kebahagiaan dalam pernikahan tersebut, ibu Ros Mini juga ikut menikmati suasananya. Dalam segmen ini juga akan dimasukan lagu kidung saweran, salah satu tradisi pernikahan sunda. Kidung akan dinyanyikan sembari menyawer para tamu undangan menggunakan uang koin, permen dan beras.

Segmen yang ke empat adalah ketika ibu Ros Mini melahirkan anak 
pertama. Harapan - harapan yang sempat dia miliki beliau sematkan kepada anak anaknya. Beliau ingin anak-anaknya bisa mencapai apa yang dulu tak mampu beliau gapai. Dari mulai cita-cita, kebebasan dan juga pernikahan. Harapan barunya lahir bersamaan lahirnya anak pertama. Untuk pertama kalinya cinta tanpa syarat tumbuh di dalam hati Ros Mini muda. Usia tujuh belas tahun tak menjadi alasan untuk berhenti belajar menjadi ibu yang baik bagi anaknya. Penggambaran suasana ini akan di wakili dengan menetasnya telur penyu. Penyu yang baru saja menetas mewakili anak-anak dari ibu Ros Mini. Kemudian penyu kecil itu akan diambil oleh sepasang tangan. Sepasang tangan itu akan membawa penyu ini ke tepian pantai, menaruhnya dan membiarkannya berjalan ke arah deburan ombak. Penyu kecil itu berenang melawan ombak menuju samudra lepas, tempat dilarungkannya harapan dan cita-cita ibu Ros Mini.

Dalam segmen ke lima akan diceritakan bagaimana kehidupan pernikahan ibu Ros Mini ketika ditinggalkan anak pertamanya untuk mengenyam pendidikan di Jogja. Pertengkaran semakin sering terjadi antara ibu Ros Mini dan suami. Ibu Ros Mini menuntut kebahagiaanya dengan mengakhiri pernikahan mereka. Rencana ibu Ros Mini dianggap sebuah penghianatan dan Ibu Ros Mini merasa di kucilkan.

Segmen enam akan memperlihatkan Ibu Ros Mini yang didampingi anak ke 2 dan ke 3 untuk menemui anak pertama, sang anak pertama kemudian memaafkan sang ibu setelah mengetahui semuanya.

\section{Perwujudan Karya}

\section{Pra Produksi}

Praproduksi merupakan sebuah tahapan saat proses merancang dan merencanakan ide cerita berlangsung. Proses perencanaan tersebut penting untuk menghasilkan karya dokumenter yang baik.

a. Pengembangan ide

Menurut Gerzon R. Ayawaila, untuk mendapatkan sebuah peristiwa, perlu menyelam ke akar permasalahan yang merupakan jalinan sebab akibat. Dengan demikian isi representasi tidak semata berupa lintasan informasi global dan kulit permasalahan (Ayawaila, 2008:38). Menentukan sebuah ide dalam dokumenter terkadang sulit karena ide selalu berkembang serta akan memiliki cabangcabang yang banyak dan hampir semuanya menarik untuk diangkat. 
b. Riset

Ide dasar penciptaan
dokumenter "MINI STORY" ini
terinspirasi dari kisah nyata,
bahkan bisa dibilang ikud di
dalamnya. Mendengar langsung
dari narasumber selama bertahun-
tahun membuat data yang
didapatkan sangat otentik, bahkan
sampai bisa merasakan segala
macam kejadian yang narasumber
alami.

Objek dari film "MINI STORY' ini adalah ibu kandung dari sang sutradara. Dengan kedekatannya dengan sang ibu, membuat objek dari film ini amat dikenali oleh sang sutradara.

\section{c. Treatment}

\section{Treatment merupakan} sketsa yang dapat memberikan gambaran pendekatan dan keseluruhan isi cerita dokumenter. Treatment mutlak diperlukan bagi dokumenter, meskipun tidak ada yang baku dalam bentuk dan penulisan tratment (Ayawaila, 2008:38). Pada proses produksi, terkadang peristiwa di lapangan tidak sama dengan apa yang telah dibayangkan, banyak hal-hal baru yang muncul dan sering kali menarik. Tidak semua hal yang ditemui di lapangan dapat kita masukkan ke dalam cerita dokumenter, terlalu banyak materi membuat cerita tidak terfokus pada permasalahan. Untuk mengantisipasi hal tersebut makan diperlukan treatment, sekaligus sebagai panduan pada proses produksi agar tetap pada pokok bahasan dan tidak melebar pada permasalahan lain.

\section{Produksi}

a. Wawancara

Wawancara adalah proses pencarian fakta melalui narasumber atau seorang yang berkompeten dalam bidangnya. Inti dari sebuah wawancara adalah mendapatkan sebuah informasi dari seorang yang memiliki kapasitas untuk menyampaikan informasi tersebut, sehingga nilai faktual dari sebuah peristiwa tetap terjaga.

Proses wawancara dalam film dokumenter poetic "MINI STORY" sudah dilakukan sebelum adanya ide pembuatan film tersebut. Posisi sutradara sebagai anak Ros Mini menjadikan informasi yang didapatnya setiap hari menjadi 
bawah yang setara dengan wawancara.

b. Pengambilan gambar

Footage/stock

shoot

merupakan gambar yang digunakan untuk memperkuat informasi yang ingin disampaikan. Footage dapat lebih menjelaskan mengenai informasi yang diberikan melalui sebuah wawancara. Fakta berupa gambar akan lebih banyak memberikan informasi daripada pendapat dari narasumber. Untuk pengambilan footage dalam tratment telah tertulis mengenai apa saja gambar yang dibutuhkan sebagai penunjang wawancara.

pengambilan

footage

dilakukan diberbagai tempat dan berbagai pantai. Latar tempat lebih didominasi oleh pantai jadi membutuhkan banyak stock shoot pantai. Selain pantai, footage yang dibutuhkan adalah adegan proses merias pengantin dan acara pernikahan yang di dalamnya ada tokoh Ros Mini.

pada tanggal 12 sampai 16 Juni 2019 dilakukan pengambilan footage pernikahan. Footage ini dibutuhkan untuk kebutuhan gambar segmen 3 yang menceritakan tokoh Ros Mini yang mengerjakan profesinya sebagai perias pengantin.

Pada tanggal 16 November 2019 dilakukan pengambilan gambar adegan proses merias pengantin yang dilakukan oleh Ros Mini sendiri. Footage ini untuk kebutuhan gambar untuk segmen pertama.

Pada tanggal 11 oktober 2019, 19 Juli dan 7 Agustus dilakukan pengambilan gambar di pantai untuk kebutuhan seluruh footage dalam film dokumenter "MINI STORY'. Pantai yang digunakan adalah pantai Goa Cemara dan Samas, pantai Pelangi dan pantai Juwok Gunung Kidul.

c. Pengambilan gambar untuk referensi animasi

Pada tanggal 5 November 2019 dilakukan pengambilan gambar untuk referensi pembuatan animasi. gambar dan video yang diambil akan digunakan sebagai pedoman pembuatan animasi. Video tersebut akan memudahkan pengerjaan animasi dan akan memperhalus hasil akhirnya.

\section{Pasca Produksi}

Pasca produksi dilaksanakan setelah proses produksi selesai. Pada 


\section{Abdurrahman Kholid Rusadi, Agnes Widyasmoro, Andi Nur Patrio}

Makna Pernikahan Menurut Sudut Pandang Tokoh Ros Mini Dalam Dokumenter P oetic " mini story"

tahap ini akan dikakukan proses editing mulai dari offline hingga online editing. Dalam offline editing, ada proses pembuatan animasi sebagai elemen utama pembangu film. Gambar dan animasi disusun berdasarkan treatment yang telah dibuat sehingga menjadi sebuah kesatuan cerita yang utuh. Sebelum masuk ke tahap online editing, terlebih dahulu dilakukan proses voice over. Online editing terdiri dari proses memasukan visual effect, grading, sound effect, sound mixing dan mastering.

a. Pengarsipan data produksi

Pengarsipan data produksi dilakukan dengan cara mengklasifikasikan data hasil produksi sesuai hari dan lokasi. Setelah diklasifikasikan sesuat heri dan lokasi, kemudian disortir sesuai kebutuhan sekmen.

\section{b. Editing offline}

Editing offline merupakan tahapan pertama dalam menggabungkan dan menyusun sebuah gambar. Dalam tahapan ini gambar disusun berdasar editing script, dalam tahapan ini pula pemilihan gambar footage dilakukan baik digunakan sebagai penguat wawancara maupun sebagai media penyampaian pesan kepada penonton. Hasil dari tahap ini merupakan sebuah struktur informasi yang utuh.Dalam penciptaan karya ini, sutradara merangkap sebagai editor. Dengan demikian materi film akan mudah dihafal dan dapat melakukan penyusunan materi dengan cepat.

\section{c. Pembuatan Animasi}

Sebelum pembuatan animasi, terlebih dahulu harus mempersiapkan pedoman gerakan. Metode animasi yang digunakan dalam film ini adalah rotoscoping. Video asli akan di gambar per frame secara digital, sehingga menghasilkan animasi yang lembut dan rapi. Animasi yang di buat antara 12 sampai 15 Frame per secon.

\section{d. Editing script}

Naskah dari sebuah dokumenter dibuat pada saat editing dilaksanakan. Editing script berisi susunan cerita lengkap berupa gambar dan suara.

\section{e. Editing online}

Tahapan ini adalah tahap akhir dari proses perwujudan karya. Dalam tahap ini hasil dari editing offline dihaluskan dan diberi visual effect termasuk efek 
transisi. Tujuan dari tahap ini adalah untuk memberikan nilai estetis pada sebuah karya audio visual.

\section{f. Audio mixing}

Proses audio mixing merupakan sebuah tahapan akhir untuk meratakan volume suara sehingga tidak ada suara yang berlebihan. Selain itu pada tahap ini juga ditambahkan musik ilustrasi sebagai penambah mood dalam film.

\section{Pembahasan Karya}

Film dokumenter poetic "MINI STORY" menyampaikan perasaan anak terhadap perjalanan pernikahan ibunya yang mengalami perjodohan. Sutradara sebagai anak dari Ros Mini yang memutuskan untuk bercerai di usia pernikahan yang ke 25 tahun. Sutradara sebagai anak yang mengetahui segala cerita kehidupan pernikahan Ros Mini dan mencoba memahami alasan Ros Mini memilih bercerai dengan suaminya. Perasaan Sang anak ketika mengetahui kejadian sebenarnya yang menimpa Ibunya digunakan untuk membangun kesedihan dan rasa bersalah yang dirasakan oleh anak Ros Mini.

Cara menyampaikan informasi dalam film dokumenter "MINI STORY" bermacam-macam. Informasi disampaikan melalui lagu, penggunaan animasi dalam menggantikan tokoh Ros Mini, bentuk film yang dibuat menyerupai film lawas serta penataan artistik. Setiap segmen memiliki pembahasannya dan motivasinya masingmasing.

Elemen objek yang ada dalam film "MINI STORY" memiliki muatan metafora. Objek tersebut juga mengandung filosofi yang dapat dikaitkan dengan bentuk kehidupan manusia. Objek tersebut adalah penyu, pantai, laut, candi dan hutan.

\section{Segmen $1 \mathrm{~A}$}

a. Aspek Kenangan Masa Lalu

Aspek kenangan pada segmen ini diaplikasikan menggunakan efek editing yang menyerupai film lawas. Hal itu bertujuan menstimulus rasa rindu sehingga membangkitkan kenangan. Video yang memperlihatkan Ros Mini sedang merias perempuan muda menggambarkan kejadian masa lalu yang Ros Mini alami. Dia mengalami perjodohan dan pernikahan dini. Ros Mini merias wajah anak kecil itu sampai terlihat seperti pengantin perempuan dengan riasan adat suku sunda. Segmen 1 dijadikan sebagai bagian pengenalan dari film dokumenter "MINI STORY", hal yang pertama kali ditampilkan adalah pernikahan yang mempengaruhi seluruh kehidupan Ros Mini.

\section{b. Aspek Metafora}

Ros Mini sedang merias seorang anak kecil di hadapannya. Dia seolah 
berhadapan dengan dirinya di masa lalu. Dengan telaten dia merias dari awal sampai akhir sampai proses meriasnya selesai. Setelah anak kecil itu menjadi pengantin perempuan dengan riasan adat sunda, tiba-tiba Ros Mini terdiam. Dia melihat wajah anak kecil tersebut. Secara perlahan tubuh Ros Mini berubah menjadi gambar, perempuan kecil di hadapannya menjadi wajah Ros Mini dengan riasan pengantin yang lengkap.

Metafora yang dibangun dalam segmen ini menceritakan jati diri Ros Mini yang sudah menghilang bersamaan dengan pernikahan yang dialaminya. Warna putih dari perubahan bentuk animasi pada diri Ros Mini adalah gambaran dampak pernikahan yang menyebabkan hilangnya semua harapan dan menyisakan diri Ros Mini yang kosong. Gestur menyentuh wajah dirinya sendiri adalah bentuk penyesalan yang harus ditanggung selama hidupnya. Nyanyian kidung panganten yang berisi doa-doa untuk para mempelai tak diraskan Ros Mini dalam menjalani kehidupan pernikahannya.

Pencahayaan low key memperkuat keintiman dan kedalaman kesan suram dari kejadian pernikahan Ros Mini pada waktu itu. Aura kebahagiaan dari seorang pengantin tereduksi atau bahkan mengilang akibat pencahayaan yang digunakan. Segmen 1A digunkan untuk mewakili kondisi kejadian dan perasaan hati Ros Mini ketika menjalani pernikahannya. Pernikahan yang seharusnya membahagiakan tidak terjadi dalam pernikahan tokoh Ros Mini.

\section{Segmen 1B}

a. Aspek Kenangan Masa Lalu

Segmen 1A menceritakan kondisi hidup Ros mini ketika sebelum terjadinya pernikahan. Minat belajarnya yang besar dan cita-cita nya menjadi seorang dokter terpaksa dia hentikan. Ros Mini muda tak pernah membayangkan akan menikah diusianya yang ke 17 tahun. Diusia segitu Ros Mini baru menyelesaikan pendidikan sekolah menengah pertama (SMP).

b. Aspek Metafora

Ros Mini sedang duduk di pinggir pantai sembari melihat ke arah laut lepas. Adegan ini menggambarkan bahwa Ros Mini ingin pergi dari pantai menuju ke laut lepas. 3 tokoh yang sedang bermain di tepi pantai adalah anak-anak Ros Mini. Anakanak Ros Mini sedang asyik bermain di tepi pantai dan anak tertua mendapatkan seekor penyu yang membuat adiknya bahagia. Adegan ini menggambarkan kehidupan anak-anak Ros Mini yang penuh kebebasan. Mereka bisa melewati garis pantai dan bermain air laut, sedangkan Ros Mini hanya menyaksikan dari kejauhan yang mengartikan bahwa dia tidak bisa melakukan hal seperti itu. Garis pantai di dalam segmen 1B merupakan metafora dari garis yang memisahkan diri seseorang dari 
kebebasannya. Bibir pantai adalah penggambaran dari kehidupan yang terpaksa Ros Mini jalani. Garis pantai memisahkan Ros Mini dengan kehidupan impiannya, impian itu digambarkan sebagai hamparan samudra. Kehidupan sangat luas seperti metafora sebuah samudra, namun Ros Mini hanya bisa menjalani sebesar pulau itu saja.

Manusia digambarkan seperti seekor penyu, pantai adalah rahimnya dan samudra adalah kehidupannya. Samudra adalah tempat di mana keringat dan airmata bercampur, menjadi asin yang dikecap seumur hidupnya. Sejauh apapun mereka pergi, mereka akan kembali ke tempat mereka lahir. Menetaskan telur-telur mereka dan begitu seterusnya. Ros Mini adalah seekor penyu yang tak bisa pergi dari pantainya. Dia tak sempat menemukan kehidupan di luar selain yang ada di pantai dan di pulau tersebut. Pengalaman hidupnya hanya sebatas garis pantai. Ada bagian yang hilang dari hidup Ros Mini, menjadikan kosong yang tak sanggup terisi karena kekosongannya adalah tentang waktu dan waktu tak akan bisa dibalik.

Penyu diperlihatkan diakhir segmen 1B. Penyu yang sedang merangkak menuju arah pantai kemudian ditarik oleh sepasang tangan sebagai gambaran bahwa Ros Mini tidak bisa pergi kemana-mana.

\section{Segmen 2B}

a. Aspek Kenangan Masa Lalu
Segmen ke 2 dalam film dokumenter "MINI STORY" menceritakan kejadian ketika Ros Mini mengetahui akan dinikahkan . Ros Mini sempat kabur dari rumah. Karena Ros Mini tidak pernah punya pengalaman pergi jauh, akhirnya dia lari ke tempat sahabat dekatnya. Sahabat dekatnya memiliki nasib yang jauh berbeda dengan dirinya. Sahabatnya masih bisa mengenyam pendidikan dan melanjutkan ke bangku SMA. Ros Mini berharap akan dibela oleh keluarga temannya ketika pihak keluarganya menjemputnya pulang.

Setelah beberapa hari tinggal di rumah temannya, Ros Mini dijemput oleh kakaknya. Sang kakak memiliki siasat tersendiri supaya pihak keluarga temannya tidak menahan Ros Mini dan Ros Mini juga mau ikut dengannya. Sang kakak mengajak Ros Mini pergi ke Jambi, ke tempat kakak laki-lakinya yang paling tua. Ros Mini kemudian menerima tawaran kakaknya dan akhirnya pergi ke Jambi.

Setelah beberapa minggu di Jambi, kakaknya yang mengajak pergi ke Jambi mengajak Ros Mini pulang ke rumah orangtuanya di Tasikmalaya. Setelah mereka sampai di Tasikmalaya, acara pernikahan Ros Mini masih tetap digelar.

b. Aspek Metafora

Metafora yang ditonjolkan disini adalah sebuah perjalanan yang dijalani oleh Ros Mini. Ros Mini berjalan di bibir pantai kemudian masuk ke hutan pinggir pantai. 


\section{Abdurrahman Kholid Rusadi, Agnes Widyasmoro, Andi Nur Patrio}

Makna Pernikahan Menurut Sudut Pandang Tokoh Ros Mini Dalam Dokumenter P oetic " mini story"

Ros Mini kemudian berjalan di jalan lurus yang masih ada pepohonannya dan sampai ke sebuah jalan terowongan yang mewakilkan pembangunan. Ros Mini kemudian mulai masuk ke hutan dan berjalan menuju sebuah situs candi yang terletak diatas gunung.

Ada dua makna perjalanan yang dilakukan Ros Mini, yang pertama perjalanan Ros Mini untuk mencari harapan dan upaya melarikan diri dari hal yang tidak dia inginkan dan yang kedua adalah perjalanan pernikahan yang diumpamakan seseorang yang hidup di sebuah pulau. Ros Mini pergi dari pantai menuju ke dataran tinggi yang disana terdapat sebuah candi. Hal itu metafora dari upaya pencarian ketenangan dalam kehidupan pernikahannya. Keberadaan candi di atas gunung menggambarkan spiritualitas yang tinggi dan disana Ros Mini mendapatkan ketenangan dalam hidup. Setelah dia pergi dari candi tersebut dan kemudian kembali turun ke pantai, Ros Mini masih merasakan rasa sakit akibat kenyataan yang dialaminya.

\section{Segemen 2B}

a. Aspek Kenangan Masa Lalu

Segmen $2 b$ dalam segmen ini adalah selingan dari segmen 2 ke segmen 3 . Segmen $2 b$ menceritakan tentang mimpi yang terus terulang dalam tidur Ros Mini. Ros Mini selalu bermimpi membawa tas dan berangkat ke sekolah, mimpinya tersebut adalah efek dari trauma akibat pengalaman pernikahan yang dia alami. Perasaan tidak adil juga memperparah trauma Ros Mini. Ros Mini merasa tidak diberi keadilan setelah mengetahui saudara perempuannya bisa mendapatkan apa yang tidak dia dapatkan.

\section{b. Aspek Metafora}

Segmen $2 b$ memperlihatkan animasi seseorang yang berjalan dalam kegelapan. Adegan ini mewakilkan perasaan Ros Mini menghadapi ketidak adilan yang dia alami. Ros Mini seolah berjalan dalam kesedihan tanpa ada satupun dukungan.

\section{Segmen 3}

Segmen 3 menceritakan tentang perasaan yang dialami oleh Ros Mini ketika menjalani acara pernikahannya. Sudut pandang dalam segmen 3 lebih didominasi oleh sutradara. Segmen 3 memperlihatkan kemeriahan acara pernikahan yang berlangsung dengan adat budaya suku sunda. Ros Mini berada di acara pernikahan tersebut sebagai seorang perias pengantin, di dalam acara tersebut juga Ros Mini menikmati kemeriahannya. Kemeriahan itu dirasakan oleh para pengantin yang melangsungkan pernikahan. Tanpa adanya paksaan, pernikahan terasa penuh sukacita dan kebahagiaan.

Kemeriahan, sukacita dan kebahagiaan juga terjadi dalam pernikahan Ros Mini tapi tidak dalam lubuk hatinya. Sutradara 
merasakan bertapa hampanya pernikahan yang Ros Mini alami. Segala hal yang lazimnya dialami oleh pasangan pengantin tidak pernah Ros Mini dapatkan dalam pernikahannya. Pernikahan seharusnya menjadi hal paling membahagiakan, dalam hidup Ros Mini pernikahan justru menjadi hal yang paling menyakitkan.

\section{Segmen 4}

a. Aspek Kenangan Masa Lalu

Segmen 4 dalam film dokumenter poetic "MINI STORY" menceritakan kelahiran anak pertama. Pada tanggal 19 Maret 1995 anak pertama Ros Mini lahir. Kondisi fisik sang anak sangat lemah ketika lahir. Sang anak tidak langsung menangis, butuh penanganan medis untuk membuat sang anak menangis. Badan sang anak dijungkir balikan dan ditepuk tepuk pundaknya supaya mengeluarkan cairan dari paru parunya. Setelah sekian lama penanganan medis yang dilakukan, barulah sang anak menangis.

b. Aspek Metafora

Segmen 4 diawali dengan suara deburan ombak, kemudian visual memperlihatkan sebuah buku. Sepasang tangan kemudian mengambil beberapa helai kertas kalu diletakan. Setelah beberapa saat dari kertas itu keluar seekor anak penyu. Adegan ini adalah sebuah metafora dari kelahiran seorang anak. Suara pantai memberikan suasana pantai sebagai tempat alami telur penyu menetas.
Sebuah buku melambangkan sebuah buku kehidupan.

Dua pasang tangan yang tadi menyobek kertas kemudian mengambil anak penyu dengan perlahan. Sepasang tangan tersebut berubah menjadi animasi ketika menyentuh anak penyu. Secara perlahan anak penyu diangkat sampai visual menggelap. Tangan yang mengambil anak penyu adalah metafora pertolongan yang harus didapatkan oleh anak Ros Mini. Di alam liar, telur penyu menetas sendiri dan tidak mendapatkan bantuan untuk sampai ke air laut. Adegan ini juga menjadi metafora tentang kondisi anak yang dilahirkan dari perempuan yang masih berusia remaja. Akibat dari tubuh yang belum siap menjalani kehamilan, mengakibatkan bayi yang dilahirkan dalam kondisi lemah dan beresiko mengalami kematian parental.

Dua pasang tangan yang membawa penyu kemudian melepaskan penyu dipantai. Sang penyu berjalan ke arah pantai dengan gerakan zig-zag. Dua pasang tangan tadi membantu mengarahkan jalan anak penyu agar lurus ke arah laut lepas. Adegan ini adalah metafora dari pembebasan seorang ibu kepada anaknya. Kedua tangan yang meluruskan jalan anak penyu adalah metafora seorang ibu mengerahkan anaknya supaya bisa selamat sampai pada apa keinginannya. 
Setelah meletakan anak penyu, pemilik tangan itu kemudian berdiri lalu menjatuhkan kepalanya di pangkuan seorang perempuan. Warna tubuhnya berupa ketika perempuan itu menyentuh kepalanya. Adegan ini menggambarkan sebuah hal yang terjadi dalam hubungan ibu dan anak. Seorang yang tidur di pangkuan seorang anak adalah gambaran kasih sayang seorang ibu. Belaian dari seorang ibu memberikan kasih sayang yang akan mewarnai sifat dan watak sorang anak.

\section{Segmen 5}

\section{a. Aspek Emosional}

Anak pertama beranjak dewasa dan harus pergi dari rumah. Kejadian itu menjadi kesedihan bagi Ros Mini. Ros Mini mulai merasa pernikahan yang selama ini dijalani sudah mulai kehilangan arti. Karena merasa pernikahannya sudah tidak ada artinya lagi, Ros Mini kemudian menggugat cerai suaminya.

b. Aspek Metafora

Adegan dalam segmen 6 menceritakan perjalanan Ros Mini dengan anak pertamanya. Adegan dimulai ketika Ros Mini berjalan ke tengah kemudian terjadi timelapse dari dia mengandung sampai anaknya dewasa. Kemudian sang anak pergi meninggalkan Ros Mini. Secara perlahan suaminya berada di belakangnya. Ros Mini langsung marah kepada suaminya dan menyuruh dia pergi.
Ketika berjalan, Ros Mini ditampar dari dua sisi sampai membuatnya tersungkur. Setelah tersungkur Ros Mini mencoba berdiri namun ditendangi sehingga kembali terjatuh. Adegan ini metafora tuduhan dan penghakiman yang jahat terhadap Ros Mini yang memutuskan untuk bercerai. Adegan ini juga mewakili kejadian yang sering terjadi dimasyarakat, dimana perempuan akan menjadi sumber tuduhan dari kesalahan yang terjadi dalam rumahtangga.

Secara perlahan anak pertama berada di hadapan Ros Mini. Ros Mini meminta bantuan namun sang anak malah pergi meninggalkannya. Adegan ini menggambarkan kemarahan yang dirasakan sang anak ketika Ros Mini memutuskan untuk bercerai.

\section{Segmen 6}

a. Aspek Emosional

Ros Mini mendapatkan banyak hujatan dari berbagai pihak. Membuat Ros Mini dikucilkan. Tidak ada yang menemani Ros Mini dalam keadaan terlemahnya, termasuk anak pertamanya. Kondisi terberat dan segala duka citanya Ros Mini tanggung semuanya sendiri.

Seiring berjalannya waktu anak-anak kedua dan ketiga mulai memberikan dukungan pada Ros Mini. Mereka mulai merasakan kesakitan yang dialami oleh ibunya. Secara perlahan Ros Mini mulai bangkit. Anak-anaknya sudah mual 
menerima keputusan ibunya untuk bercerai dengan ayahnya. Hal itu pula yang dirasakan oleh anak pertama. Dia mulai memahami apa yang sebenarnya terjadi pada ibunya. Keputusan berpisah dengan ayahnya tidak lagi terlihat sebagai sebuah kesalahan. Anak pertama menjadi lebih mengerti tentang pengorbanan ibunya dalam membesarkannya. Kehidupan pernikahan yang Ros Mini jalani adalah hanya untuk anak-anaknya.

b. Aspek Metafora

Adegan dalam segmen 6 adalah ketika Ros Mini menangis sendirian dan tiba-tiba anaknya yang paling kecil memeluk dari belakang. Di kejadian nyata, anak terakhir memang yang pertama memberi dukungan. Kemudian anak ke dua datang menggenggam tangan Ros Mini, kemudian menemani di sampingnya menyusuri pantai. Anak kedua dan ketiga menemani ibunya bertemu dengan anak pertama yang sedang berada di bibir pantai. Kemudian anak pertama memeluk Ros Mini. Dalam kejadian nyata, anak pertama sudah tidak peduli dengan keluarganya. Adegan berdiri di bibir pantai adalah metafora bahwa anak pertama sudah siap meninggalkan keluarganya. Pada akhirnya anak pertama tidak jadi melakukannya dan digambarkan dengan memeluk Ros Mini.

\section{Segmen Penutup}

$$
\text { Bagian segmen penutup }
$$
menceritakan tentang upaya Ros Mini dalam mengobati depresinya. Ros Mini melanjutkan pendidikan dan meraih gelar sarjana pendidikan anak usia dini. Fotage yang digunakan adalah beberapa hasil dokumentasi pada saat Ros Mini wisuda. Bagian ini juga menceritakan tentang proses perceraian Ros Mini. Ros Mini sudah menangis dari awal persidangan. Ros Mini menceritakan bahwa tangisannya bukan karena sedih akan perceraiannya, tangisnya itu adalah hasil dari akumulasi rasa sakit yang dideritanya sedari dulu. Pada tanggal 29 april 2020, Ros Mini bercerai berdasarkan putusan Pengadilan Agama Tasikmalaya.

\section{Kesimpulan}

Film dokumenter "MINI STORY" adalah sebuah karya seni dokumenter yang menceritakan tentang seseorang yang menjalani pernikahan hasil perjodohan dan pernikahan usia dini. Film ini mampu menampung segala ekspresi, imajinasi dan emosi dari sutradara dan Ros Mini sebagai ibunya. Sutradara menjadikan film " MINI STORY" sebagai ungkapan penyesalannya. Perasaan penyesalan itu lahir ketika sutradara menghakimi Ros Mini yang memutuskan untuk bercerai, disisi lain sutradara tidak mengetahui alasannya. Ketika sutradara mengetahui alasan Ros Mini memilih untuk bercerai barulah dia merasa sangat bersalah. Ros Mini menghadapi berbagai kejadian buruk dalam 


\section{Abdurrahman Kholid Rusadi, Agnes Widyasmoro, Andi Nur Patrio}

Makna Pernikahan Menurut Sudut Pandang Tokoh Ros Mini Dalam Dokumenter P oetic " mini story"

hidupnya. Pernikahan yang tak diharapkan merampas masa remajanya. Meski demikian, Ros Mini tetap mencintai anaknya dengan tulus. Penilaian yang terlalu berburu-buru terhadap sesuatu memiliki kemungkinan besar untuk menyakiti perasaan seseorang. Film "MINI STORY" mengajarkan bahwa dalam menilai sesuatu harus di selami terlebih dahulu supaya lebih bijak dalam menyikapinya.

Yang mejadi pemaknaan pernikahan bagi tokoh Ros Mini adalah metafora kelahiran anak pertamanya yang diwakili dengan menetasnya seekor penyu. Anak sebagai makna pernikahan Ros Mini menjadi terlihat ketika sang anak pertama pergi meninggalkan rumah. Pernikahan yang didasari oleh pemaksaan dan tak ada rasa cinta pada suaminya, membuat Ros Mini menjadi kehilangan alasan untuk bertahan dalam pernikahannya.

Gaya poetic menjadi format film dokumenter yang cocok untuk film "M IN I STORY". Gaya poetic mampu mengakomodir bentuk cerita yang lebih menekankan pada perasaan emosional. Gaya poetic menekankan suasana hati, nada, dan mempengaruhi lebih dari sekedar menampilkan pengetahuan atau tindakan persuasi. Penyajiannya sangat bebas berdasarkan upaya penyampaian perasaan yang ingin dikemukakan. Poetic dalam film ini dibangun menggunakan semiotika, semiotika yang digunakan adalah jenis metafora Charles S. Pierce dengan mengeksplorasi elemen objek estetis alam. Penggunaan animasi menjadi variasi dalam mengeksplorasi bentuk visual baru dalam upaya menyampaikan perasaan sutradara. Menggunakan animasi, visual dalam film ini menjadi terlihat lebih artistik. Pesan yang disampaikan mejadi sangat padat di setiap bagiannya. Bentuknya yang personal mengesampingkan keterbacaan penonton terhadap keseluruhan pesan film. Keberhasilan film poetic adalah ketika penonton mampu merasakan perasaan yang sama dengan sutradara.

\section{Daftar Rujukan}

\section{Daftar Sumber Buku}

Ardhianita, I., \& Budi. (2005). Kepuasan Pernikahan Ditinjau dari Berpacaran dan Tidak Berpacaran. Jurnal Psikologi Fakultas Psikologi Universitas Gadjah Mada, 101-111.

Ati, A. W. (1999). Menguji Cinta - Konflik Pernikahan Cina-jawa. Yogyakarta: Tarawang Press.

Ayawaila, G. (2008). Dokumenter: Dari Ide Sampai Produksi. Jakarta: FFTV-IKJ Press.

Budiman, K. (2011). Semiotika Visual: Konsep, Isu dan Ikonisitas. Yogyakarta: Jalasutra.

Fadlyana, E., \& Larasaty, S. (2016). Pernikahan Usia Dini dan Permasalahannya. Bagian Ilmu 
Sense Vol 4 | No 1 | Mei 2021

kesehatan Anak FK Universitas

Padjajaran, 136-140.

Junaedi, D. (2017). Estetika: Jalinan Subjek, Objek dan Nilai.

Yogyakarta: ArtCiv.
Nicholl, B. (2001). Introduction To

Documentary. America: Indiana University Press.

Pratista, H. (2017). Memahami Film. Yogyakarta: Mintase Press. 
Abdurrahman Kholid Rusadi, Agnes Widyasmoro, Andi Nur Patrio

Makna Pernikahan Menurut Sudut Pandang Tokoh Ros Mini Dalam Dokumenter P oetic " mini story" 
Sense Vol 4 | No 1 | Mei 2021 